\title{
Emission of styrene from polystyrene foam and of cyclopentane from polyurethane foam - measurements and modelling
}

\begin{abstract}
Summary - Due to toxicity of volatile organic compounds (VOC), assessment of their emission from polymer dry construction materials is of importance for the quality of the indoor environment. Accordingly, in this work we studied emissions of styrene from polystyrene foam (PSf) and of cyclopentane from polyurethane foam (PURf). Both foams are common insulation materials. The partition $(K)$ and diffusion $(D)$ coefficients of these compounds in respective foams were determined at temperature between $23-90{ }^{\circ} \mathrm{C}$. The partition coefficients of foam-ambient gas system $\left(K_{M-A}\right)$ derived from the determined adsorption and desorption rate constants $\left(k_{a d s^{\prime}}, k_{d e s}\right)$ using the close-to-equilibrium theory and computer simulation, resulting in comparable values. The diffusion coefficients, by contrast, were obtained using three models based on sorption $\left(D_{S}\right)$, permeation $\left(D_{P}\right)$ and computer simulation $\left(D_{C}\right)$. In the first model, the foam is seen as a continuous phase, in the second model - as consisting of two phases where the VOC concentration is arithmetically averaged, while the third one assumes the inhomogeneous VOC distribution. Based on the same experimental data, three sets of diffusion coefficients were obtained $\left(D_{S^{\prime}} D_{P}, D_{C}\right)$, disparate in values, these disparities originating from the assumptions made in each model. The computer-simulation at relatively low migrant concentrations in the foam (styrene-PSf system), and the permeation model at high migrant concentrations (cyclopentane-PURf system) generated the diffusion coefficients comparable with results presented in the literature.
\end{abstract}

Keywords: styrene, cyclopentane, polystyrene foam, polyurethane foam, emission, computer simulation.

\section{EMISJA STYRENU Z PIANKI STYROPIANOWEJ I CYKLOPENTANU Z PIANKI POLIURETA- NOWEJ - POMIARY I MODELOWANIE}

Streszczenie - Ze względu na toksyczność lotnych związków organicznych (volatile organic compounds - VOC), oznaczanie emisji tych związków z polimerowych, suchych materiałów budowlanych ma ogromne znaczenie $\mathrm{z}$ punktu widzenia jakości środowiska we wnętrzu domów. W opisanej poniżej pracy zbadano kinetykę emisji styrenu z pianki styropianowej (PSf) oraz cyklopentanu z pianki poliuretanowej (PURf, rys. 1 i 2). Obydwie pianki są powszechnie stosowanymi materiałami izolacyjnymi. Oznaczono współczynniki podziału $(K)$ i dyfuzji $(D)$ badanych związków w piankach w zakresie temperatury $23-90^{\circ} \mathrm{C}$. Współczynniki podziału w układzie pianka-otaczający gaz $\left(K_{M-A}\right)$ obliczono z wyznaczonych wartości stałych szybkości sorpcji i desorpcji $\left(k_{a d s}, k_{d e s}\right)$ związków na piankach, z zastosowaniem kinetyki reakcji I rzędu w pobliżu stanu równowagi i symulacji komputerowej. Obydwie metody obliczeniowe dały porównywalne wyniki (tabele $1-3$ ). Natomiast do obliczenia współczynników dyfuzji związków w piankach, posłużono się trzema modelami opartymi na: sorpcji związków w piankach $\left(D_{S}\right)$, ich permeacji przez pianki $\left(D_{P}\right)$ bądź na symulacji komputerowej $\left(D_{C}\right)$. W modelu sorpcyjnym zakłada się, że pianka jest fazą ciągłą, podczas gdy w modelu permeacyjnym - składa się z dwóch faz, w których stężenie VOC jest uśrednione; model symulacyjny zakłada niehomogeniczny rozkład stężenia VOC. Wychodząc z tego samego zestawu danych pomiarowych otrzymano trzy zestawy wspomnianych współczynników dyfuzji $\left(D_{P}, D_{S}, D_{C}\right)$ różniących się wartościami (tabela 4). Różnice te są wynikiem założeń poczynionych $\mathrm{w}$ każdym modelu. Porównywalne $\mathrm{z}$ danymi literaturowymi (tabela 5) wartości współczynników dyfuzji w obszarze względnie małych stężeń migranta w piance

\footnotetext{
1) Jagiellonian University, Faculty of Chemistry, 30-060 Kraków, Ingardena 3, Poland.

2) AGH-University of Science and Technology, Faculty of Physics and Applied Computer Science, 30-059 Kraków, Reymonta 19, Poland.

*) Author for correspondence; e-mail: maciej.choczynski@uj.edu.pl
} 
(układ styren-PSf) uzyskano metodą symulacji komputerowej, a w przypadku większych stężeń (cyklopentan-PURf) - zgodnie z modelem permeacyjnym.

Słowa kluczowe: styren, cyklopentan, pianka styropianowa, pianka poliuretanowa, emisja, symulacja komputerowa.

Assessment of emissions of volatile organic compounds (VOC) from polymer dry materials used in construction industry is an important aspect of their physico-chemical investigations [1-3], which is due to toxicity of VOC. This may have impact on the quality of the indoor environment [4], on the health and general comfort of the occupants in particular. VOC are introduced to the materials as additives to improve material properties or are present in the materials as residuals of polymerization processes [5]. An example of the first group of VOC is cyclopentane used as a blowing agent during polyurethane foam manufacturing [6], and an example of the second group is styrene, a monomer in the process of polystyrene fabrication [7]. In addition to the toxicity analysis, VOC emissions are also studied to estimate the quality of polymeric materials and to investigate the ageing processes [8].

Emissions of VOC from polymeric materials are usually determined by the American (ASTM D 5116-90) or European (ENV 13419) standard test methods. Typically, in these tests emissions are determined in a relatively short time (several days) using small chambers (volume lower than $1 \mathrm{~m}^{3}$ ) at ambient temperature (the measurements at temperatures $>23{ }^{\circ} \mathrm{C}$ are infrequent [9]). However, often the information on long term emission profiles in a full-scale chamber (indoor conditions) is necessary. Normally, such measurements are time-consuming and costly, and as a result, wherever possible, they are replaced by the mathematical modeling of emissions [10-13].

The emission of VOC from polymeric materials is a process consisting of a diffusion through the material and a surface emission [2]. Diffusion, for a given system described by a diffusion coefficient, occurs under the concentration gradient. Surface emission by contrast, consists of the partition on the material-air interface described by the partition coefficient, and further of the transport in the air (diffusion and convection) $[2,10]$. The diffusion in the polymer and partition between the polymer surface and air are limiting phenomena in the emission processes [10].

For a model of emission to be developed, the knowledge of a number of input parameters is required. These include the initial concentrations of VOC in the material, in addition to partition and diffusion coefficients. The initial concentration of VOC in the polymer material may be determined by various separation methods, for instance by dissolving a polymer sample followed by precipitation of the polymer [3], by headspace analysis [14, 15], complete evaporation of the sample to a gas phase [16], or extraction of the compound to an organic solvent.
The partition coefficients at material/gas interfaces defined as the ratio of VOC concentrations in the material phase to that in air at equilibrium conditions, are commonly determined gravimetrically from the direct measurements of sorption on the material with use of the McBean balance [17, 18]. The measurements can also be performed indirectly with other techniques, such as inversed gas chromatography (IGC) [19-21], the mentioned headspace technique (HS) [14, 22, 23], acoustic sensors (surface acoustic wave - SAW or thickness shear mode - TSM) [21, 24] and the vapor pressure method [25]. Alternatively, the partition coefficients may be expressed as the ratio of VOC adsorption to desorption rate constants, and these are typically determined from the measurements of VOC sorption in dynamic experiments $[26,27]$.

The diffusion coefficients in the materials may be measured in two ways, namely by sorption and permeation [28]. Sorption methods, wherein sorption kinetics of the compound in the polymeric material is measured, make use of the relationship between the rates of sorption and of transport of the compound in the material represented by the diffusion coefficient [29-32]. Under permeation methods, the polymer material is used as a permeable membrane and the amount of compound diffusing across the membrane at a constant concentration (pressure) gradient is measured, from which the diffusion coefficient is determined [33-35].

Foams are a special type of polymer materials. They are non-homogeneous (porous) materials that can be looked at as dual phase-materials consisting of gas (cells) and solid polymer (walls). Transport of VOC in a foam involves both diffusion in the gas phase and permeation through the cell walls [36]. These phenomena depend on the properties of the migrating compounds as well as on the structure of the foam (including its geometry, distribution of the cells, thickness of their walls) and polymer density. In describing mass transport through these materials two approaches are commonly adopted. One assumes that the polymer material is homogeneous and that VOC are evenly distributed in the material [11, 37]. The other one by contrast, assumes that the material consists of two phases, where VOC are present as a gas in the cells and as an adsorbed phase in the polymer, but only those in the cells diffuse through the material $[38,39]$. Typically, this approach requires the employment of a geometrical factor representing the structural properties of the foam $[6,36]$.

In this work we studied the emission (as VOC) of styrene from polystyrene foam and of cyclopentane from polyurethane foam. The rate constants of adsorption and 
desorption of styrene and of cyclopentane were determined and used for the calculation of their material-air partition coefficients. Moreover, the rate constants were generated from a computer simulation, which was further utilized for the calculation of diffusion coefficients. In addition to the simulation, the diffusion coefficients were obtained using models based on sorption and permeation. For the sorption we adopted the model that was used, as reported in the literature, for a packing material-food simulant system [13], while for the permeation we developed a model that takes into account the diffusion of the compound both dissolved in the polymer and present in the cells.

\section{THEORY AND CALCULATION PROCEDURES}

\section{Partition coefficients}

The final mass transfer of VOC from the bulk of the material to the ambient phase at a given temperature is determined by the partition coefficient $K_{M-A}$, invariant with concentration, and defined as:

$$
K_{M-A}=\frac{\left[\mathrm{c}_{M}^{e}\right]}{\left[\mathrm{c}_{A}^{e}\right]}
$$

where: $\left[c_{M}^{e}\right]$ and $\left[c_{A}^{e}\right]$ - the equilibrium VOC concentrations in a material and ambient phase, respectively.

For low concentrations the linear Henry's sorption applies [40, 41].

Alternatively, the partition coefficient $K_{M-A}$ may be expressed as the ratio of the adsorption $k_{a d s}$ and desorption $k_{\text {des }}$ rate constants:

$$
K_{M-A}=\frac{k_{a d s}}{k_{d e s}}
$$

To determine the partition coefficients $K_{M-A}$ from equation (2), we derived the rate constants $k_{a d s}$ and $k_{d e s}$ from the experimental data with use of the close-to-equilibrium kinetics [42]:

$\frac{\mathrm{d}\left[c_{\mathrm{A}}\right]}{\mathrm{d} t}=-k_{\text {ads }}\left[c_{A}\right]+k_{d e s}\left[c_{M}\right]=-\left[c_{A}\right]\left(k_{a d s}+k_{d e s} f_{M-A}\right)+k_{d e s}\left[c_{M}^{0}\right]$

where: $f_{M-A}$ - the ratio of the volume of the ambient phase to that of the foam, $\left[c_{A}\right]$ and $\left[c_{M}\right]$ - the concentrations of the compound in the ambient gas and in the foam, respectively, $\left[c_{M}^{0}\right]-$ the initial concentration of the compound in the foam.

The rate constants were determined from the intercepts and slopes of the linear dependencies of the process rates on $\left[c_{A}\right]$ according to equation (3). Additionally, we developed three-dimensional computer simulations to generate the adsorption/desorption rate constants and the diffusion coefficients by the best fitting to the experimental data (see further text).

In contrast to $K_{M-A}$, the internal partition coefficient $K_{P-C}$ describes the distribution of the compound between the polymer and the cell gas, and accordingly is expressed by the ratio of the equilibrium concentration of the compound in the cell wall, $\left[c_{p}^{e}\right]$ to that in the cell gas, $\left[c_{C}^{e}\right]$. To calculate $K_{P-C}$ the following approach was used. The experimentally derived initial concentration of the compound, $\left[c_{M}^{0}\right]$ is the concentration in the whole material. For a density-calculated solid polymer volume, the initial concentration of the compound in the polymer before the partition process between the polymer and the cell gas has occurred, $\left[c_{p}^{0}\right]$, can be expressed by:

$$
\left[c_{p}^{0}\right]=\left[c_{M}^{0}\right] f_{P-M}
$$

where: $f_{P-M}$ - the ratio of the volume of the foam to that of the polymer.

The equilibrium concentration in the cell wall, $\left[c_{p}^{e}\right]$ was calculated by subtracting the amounts of the compound released to the cells, $\left[c_{C}^{e}\right]$, and to the chamber, $\left[c_{A}^{e}\right]$ from the initial concentration $\left[c_{p}^{0}\right]$.

Furthermore, it was assumed that only those VOC molecules were released into ambient air, which had been transferred to the gas phase of the polymer. Two parallel processes of VOC distribution in the polymer-cell/gas-air system were assumed to take place. The first one is the partition of the compound between the polymer phase and cell gas consistent with the equilibrium condition:

$$
\left[c_{C}^{e}\right]=\frac{\left[c_{P}^{0}\right]}{\left(K_{P-C}+f_{P-M}\right)}
$$

The process provided the molecules to the cells of the foam.

The second process, on the other hand, resulted in both the reduction of the concentration of the compound in the cell gas and its growth in the external phase. Finally, the internal partition coefficient $K_{P-C}$ is expressed by the following equation:

$$
K_{P-C}=\frac{\left[c_{P}^{e}\right]}{\left[c_{C}^{e}\right]}=\frac{\left[c_{P}^{0}\right]-\frac{f_{P-M}\left[c_{P}^{0}\right]}{\left(K_{P-C}+f_{P-M}\right)}-\left[c_{A}^{e}\right] f_{M-A} f_{P-M}}{\frac{f_{M-A}\left[c_{P}^{0}\right]}{\left(K_{P-C}+f_{P-M}\right)}-\left[c_{A}^{e}\right] f_{M-A}}
$$

The $f$ factors were calculated from the foam and polymer densities and from the geometry of the emission chamber. To calculate the partition coefficient $K_{P-C}$ equation (6) was transformed into the second degree polynomial function and $K_{P-C}$ was taken as its non-zero, positive solution. Clearly, the partition coefficient between the foamed polymer and the external gas phase $K_{M-A}$ [equation (2)] does not have the same value as the partition coefficient between the polymer and the cell gas $K_{P-C}$ [equation (6)], which is due to the structural and geometrical factors.

\section{Diffusion coefficients}

The starting point to describe the transfer of VOC both in the material and in the inner gas phase is Fick's second law:

$$
\frac{\mathrm{d}\left[c_{M}\right]}{\mathrm{d} t}=D \frac{\mathrm{d}^{2}\left[c_{M}\right]}{\mathrm{d} l^{2}}
$$


where: $\left[c_{M}\right]$ - the concentration of the compound in the material, $D$ - its diffusion coefficient in the material, $t$ - time, $l-$ the position (length).

The independence of diffusion coefficient from the position, time and concentration is a basic assumption in the emission models. The concentrations of VOC are usually low, which is why it can be assumed that swelling effects do not affect the diffusivity.

To derive the diffusion coefficients, models of mass transfer of VOC within polymer materials are used. In this work the following three models were employed: sorption, permeation and computational. From them three diffusion coefficients for each studied system were obtained, accordingly $D_{S}, D_{P}$ and $D_{C}$. The sorption and computational models assume that the initial distribution of the diffusing compound in the foam is homogeneous. However, in the sorption model the concentration distributions are constant during a single measurement, while in the computational model the diffusion in the three dimensional space implicates a step-by-step growth of heterogeneity of concentration distribution, and a resulting effect on the concentration gradient. A feature of the permeation model, on the other hand, is that it distinguishes two phases inside the foam, namely polymer and gas, between which the concentration distribution is determined by the internal partition coefficient $K_{P-C}$.

\section{Sorption model}

The sorption model adopted here was previously developed to describe VOC transport from polymer packing materials to food simulants [7, 13]. In the model a sample is represented by a flat sheet, infinite in thickness. This ensures that the interior concentration is not influenced by the processes. When the external (fluid) phase is well mixed, the compounds released by the material are uniformly distributed in the fluid phase. If the volume of the fluid is assumed to be infinite, the concentrations of the compounds in this phase are negligibly low. In such a case the amount of the desorbed compound is expressed by:

$$
M_{t}=2\left[c_{M}^{0}\right] \sqrt{\left(\frac{D t}{\pi}\right)}
$$

where: $M_{t}$ - the amount of the compound released by a unit of polymer area at time $t$.

The mechanical fan operating in the chamber ensured that the external phase, substantially greater than the material volume, was homogeneous. Importantly, equation (8) ignores the partition because of the relatively low concentrations of the compounds in the external phase.

\section{Permeation model}

In this approach the migration of a VOC from the foam to the external phase consists of the diffusion in the solid phase of the foam (polymer) and the permeation from the cell gas through the cell wall. The model divides the migrating compound into two populations. One population is dissolved in the polymer, while the other one is present in the cell gas, both in the amounts governed by the internal partition coefficient $K_{P-C}$ calculated from equation (6). Further, the first population diffuses only in the solid polymer, hence covers a distance that encompasses only a solid part of the foam, while the second population migrates from cell to cell across the solid polymer, hence covers a distance equal to the length of the foam. Both the above distances were averaged to obtain the weighted means of the migration paths in the three dimensional space. In reality, due to the fact that the fraction of gas phases in foams is high, a majority of migrant molecules in foams proceed by doing multiple permeations through the polymer phase. The diffusion in the gas phase is a number of orders of magnitude faster than in the polymer phase, which is why the resulting diffusion coefficients have the values between those characteristic of the two phases. In this model the multiple adsorption and desorption processes are seen as a single act expressed by the partition coefficient, and the whole polymer phase is treated as homogeneous.

Diffusion coefficients were calculated from equation (7) where the concentration gradients were defined as a sum of the spatially averaged gradients: one on a polymer-cells distance (only polymer fraction thickness) and the other one - on a cell-ambient phase distance (material thickness). The permeation model includes the concentrations both in the external gas phase, $c_{A}$, and in the cell gas, $c_{C}$, the latter calculated from the formula:

$$
c_{C}=\frac{\left[c_{P}^{0}\right]}{\left(K_{P-C}+f_{P-M}\right)}
$$

It was assumed that the distance covered by the diffusion, $l$, was equal to half the sample thickness. In the experiment, the rate of the migrant concentration $c_{M}$ change in the material was directly proportional to the concentration $c_{A}$ change in the chromatographically analyzed external phase, with $f_{M-A}$ equal to the ratio of the volume of the external phase to that of the material, being a factor. It was assumed that the equilibrium in the cell-polymer systems was reached rapidly. Clearly, the permeation model proposed is a simplification of the real diffusion in the foam in that it ignores the fact that the mass transfer consists primarily of the cell to cell migration.

\section{Computer simulation}

The computational model of the VOC transport in the foam was developed under three theoretical assumptions: a) the motion of the compound inside the foam is described by the diffusion [equation (7)], b) the compound exchange between the foam surface and the ambient air consists of adsorption and desorption processes described by equation (2), c) the transport of the compound in the air surrounding the foam is several 
orders of magnitude faster than inside the foam. In consequence, in the model the three-dimensional concentration of the compound in the ambient air is uniform and is exclusively a function of time. A difference between the permeation and the computational model lies in the approach to the structure of the investigated material, namely the computational model does not take into account the existence of the gas and solid phases.

The computational modeling was created using the finite elements method. The mesh grid for the foam samples had $126000(30 \times 30 \times 140)$ cubic cells. The boundary and the initial conditions were the same as in the experiments. The initial styrene and cyclopentane concentrations in the ambient air were set to null and the initial concentrations in the foams were assumed to be homogeneous.

The first order differential method was used for solving equation (3) and (7) for the process simulation. During the simulation the time step interval of one second was applied. The coefficients $D, k_{a d s}$ and $k_{d e s}$ were the parameters of the model. The spatial and temporal function of the concentrations of the compounds in the polymers, $c_{P}$ and the time function of their concentrations in the air, $c_{A}$, were obtained from the simulations. The values of $D, k_{a d s}$ and $k_{d e s}$ were derived based on the experimental and simulated sets of data. To this end the simulation code was combined with the optimization code. The optimization code used the Nelder-Mead Simplex Method [43] to find the optimal values of the constants of interest by comparing the experimental and simulated data. The iteration method was applied and the least squares method was used for optimization. Both codes were prepared in Matlab computation environment. Using a fast PC one set of data was computed within 2-4 hours.

\section{EXPERIMENTAL}

\section{Materials}

Polystyrene (PSf) and polyurethane (PURf) foams were commercial products. PSf (density $0.025 \mathrm{~g} \mathrm{~cm}^{-3}$ ) was in the form of a board and PURf (density $0.037 \mathrm{~g} \mathrm{~cm}^{-3}$ ) was a rigid heating pipe insulation. The samples to be analyzed were cut out of the interior of the bigger foam pieces. For the density measurements the samples $15 \times 10 \times 8 \mathrm{~cm}$ were weighed with $\pm 1 \mathrm{mg}$ accuracy, giving the uncertainty of density determinations $<0.01 \%$. For an emission experiment four samples with the total volume of $30 \mathrm{~cm}^{3}$ and the total surface area of $120 \mathrm{~cm}^{2}$ were used. High purity helium with 2 ppm oxygen content, containing less then 3 ppm of moisture, was used as the carrier gas. Styrene and cyclopentane (both $99.8 \%$ ) were supplied by Fluka, methanol and dichloromethane (both of HPLC grade) supplied by Merck.

\section{Apparatus and experimental procedures}

The emissions of styrene and cyclopentane from the respective foams were measured in a test chamber, 800 $\mathrm{cm}^{3}$ in volume. The chamber, placed in a gas thermostat, was equipped with a temperature sensor and a fan, the latter to ensure effective mixing of a gas in the chamber interior. The foam samples were set on a perforated stainless steel support and rapidly introduced into the chamber, after which the chamber was tightly closed. The gas in the chamber was analyzed for styrene or cyclopentane at time intervals on a gas chromatograph. For that the chamber was directly connected to a HP 6890 gas chromatograph equipped with a HP-5MS column (5\% diphenyl $+95 \%$ polydimethylsiloxane, $30 \mathrm{~m}$ long, $0.25 \mathrm{~mm}$ internal diameter, film thickness $0.25 \mu \mathrm{m})$. HP 5973 mass quadruple spectrometer was used as the detector, working in SIM mode (Single Ion Monitoring) at 104 $\mathrm{m} / \mathrm{z}$ (mass to charge ratio) for styrene, and at $42 \mathrm{~m} / \mathrm{z}$ for cyclopentane. HP 7694E headspace autosampler was slightly modified to cooperate with the sample loop injector of the gas chromatograph. Gas flow, forced by the membrane pump, was directed from the chamber through the sample loop to return to the chamber. When the six-port valve altered its position, the carrier gas washed out the compounds from the sample loop to the chromatograph inlet. The time required to develop a chromatogram and to prepare the chromatograph for a subsequent analysis (7-10 $\mathrm{min}$ ) was a limiting factor for the time intervals applied. The emission measurement series were carried out for both kinds of the foams (PSf and PURf) at the following chamber temperatures: 23, 30, 40, $50,60,70,80$ and $90^{\circ} \mathrm{C}$, with an accuracy of $\pm 0.5^{\circ} \mathrm{C}$.

The calibration of the system for the styrene and cyclopentane determinations was carried out according to the exponential dilution procedure [44]. The gas standards were prepared in helium. The procedure allowed collecting numerous calibration points within the linear range $0.0001-1 \mu \mathrm{g} \mathrm{cm}^{-3}$ for styrene and $5-10000 \mu \mathrm{g} \mathrm{cm}^{-3}$ for cyclopentane.

To determine the initial concentration of styrene inside PSf, a sample of the foam of about $10 \mathrm{~cm}^{3}$ in volume was dissolved in $2 \mathrm{~cm}^{3}$ of dichloromethane and then the polymer was precipitated with $1 \mathrm{~cm}^{3}$ of methanol [3]. The concentration of styrene in the methanol-dichloromethane mixture was carried out using the external calibration done in the same mixture of the solvents. The resulting concentration of styrene in PSf was determined to be $5.01 \pm 0.20 \mu \mathrm{g} \mathrm{cm}^{-3}$ of PSf.

Unlike polystyrene, polyurethane foams are insoluble in most organic solvents, which is why the initial concentration of cyclopentane in PURf was determined separately in the cell gas and in the solid polymer. To analyze the cell gas, a PURf sample was crushed in a hermetic stainless steel container at $100{ }^{\circ} \mathrm{C}$ and the released gas was analyzed by GC according to the procedure reported in the literature [36], only slightly modified. To determine 

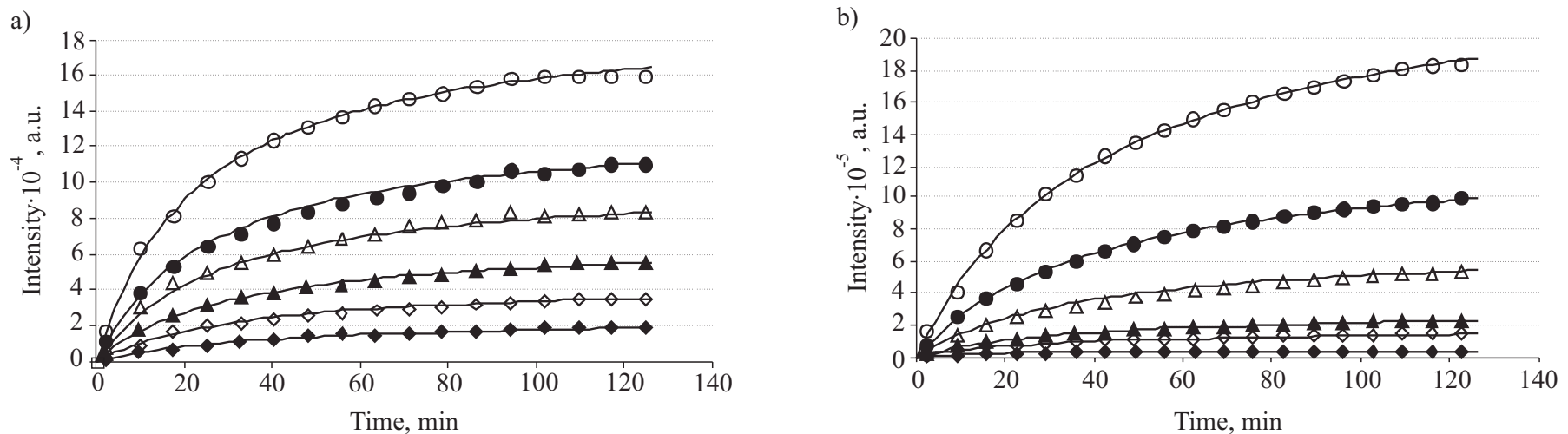

Fig. 1. Kinetic curves of the emission of: (a) styrene from polystyrene foam, and (b) cyclopentane from polyurethane foam, at $30^{\circ} \mathrm{C}$ $\diamond, 50{ }^{\circ} \mathrm{C} \diamond, 60{ }^{\circ} \mathrm{C} \boldsymbol{\Delta}, 70{ }^{\circ} \mathrm{C} \triangle, 80^{\circ} \mathrm{C} \bullet, 90^{\circ} \mathrm{C} \bigcirc$

the cyclopentane concentration in the solid polyurethane, the crushed PURf was frozen and ground into powder. Then it was placed in the hermetic glass container and the cyclopentane concentration was determined by static headspace technique at $280^{\circ} \mathrm{C}$. The overall concentration of cyclopentane in PURf was taken as the sum of that in the cell gas and in the polymer and it turned at to be $475 \pm$ $25 \mathrm{\mu g} \mathrm{cm}^{-3}$ of PURf. The calibration curves for the cyclopentane determination were obtained with the use of the hermetic stainless steel and glass containers.

\section{RESULTS AND DISCUSSION}

\section{Emission measurements}

The concentrations of styrene and of cyclopentane released from the foams to the gaseous phase were expressed as chromatographic peak areas. The typical kinetic curves describing the emissions for different temperatures are presented in Fig. 1a for styrene-PSf and Fig. $1 \mathrm{~b}$ for cyclopentane-PURf. The observed time for the equilibrium between the foams and the ambient gas to be achieved was around $100 \mathrm{~min}$ for both styrene-PSf and cyclopentane-PURf systems. The amount of the compounds released from the foams increased strongly with temperature. For both systems these curves were best described by hyperboles. From the equations of the hyperboles, the process rates $\mathrm{d} c_{A} / \mathrm{d} t$ at different times of the process were calculated.

\section{Adsorption and desorption rate constants}

To calculate the adsorption and desorption rate constants, $k_{a d s}$ and $k_{d e s}$, the process rates $\mathrm{d} c_{A} / \mathrm{d} t$ were plotted against $c_{A}$ according to equation (3). The concentrations of the compounds in the materials and in the cell and polymer phases were calculated from the mass balance using the initial concentrations of the compounds in the foams, the concentrations in the chamber, as well as the volumes of the chamber, of the foams and of the solid polymers in the foams.

The plots for different temperatures are presented in Fig. 2a for styrene-PSf and in Fig. 2b for cyclopentane-PURf. In accordance with equation (3) the rate con- a)

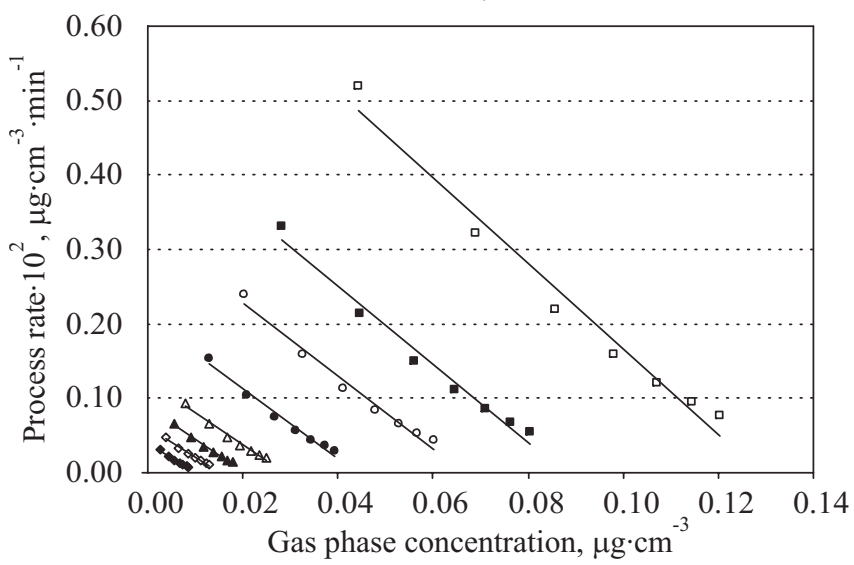

b)

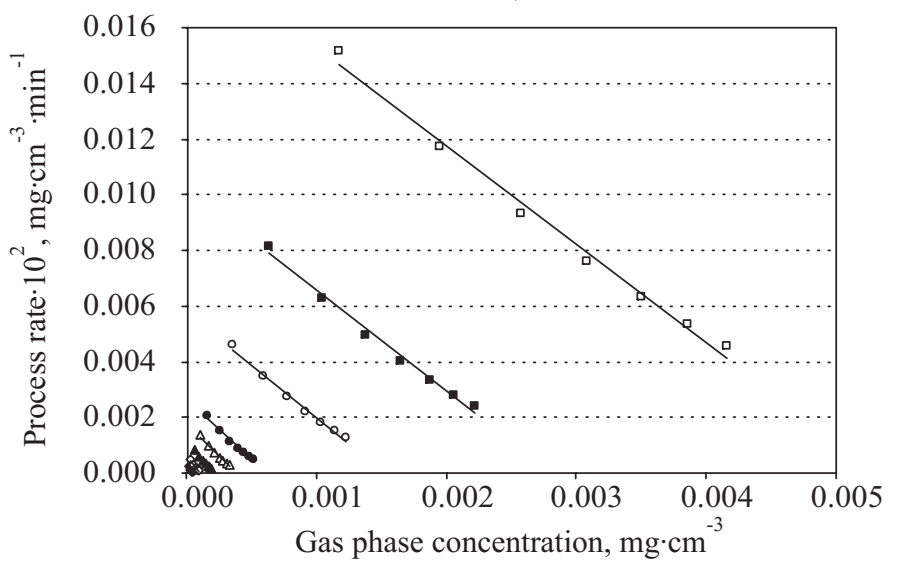

Fig. 2. Process rate as a function of concentration in the chamber for the emission of: (a) styrene from polystyrene foam, and (b) cyclopentane from polyurethane foam, at $23{ }^{\circ} \mathrm{C} \diamond, 40^{\circ} \mathrm{C} \diamond, 50^{\circ} \mathrm{C} \triangle, 60{ }^{\circ} \mathrm{C} \boldsymbol{\bullet}, 70^{\circ} \mathrm{C} \bigcirc, 80{ }^{\circ} \mathrm{C} \mathbf{\square}, 90^{\circ} \mathrm{C}$ 
stants of desorption $k_{d e s}$ and of adsorption $k_{a d s}$ were calculated from the values of intercepts and slopes of the lines. The results are listed in Table 1 . The computer simulation-derived rate constants $k_{a d s}$ and $k_{\text {des }}$ by contrast, are presented in Table 2.

T a b l e 1. Rate constants of adsorption and desorption, $k_{a d s}$ and $k_{d e s}$ and partition coefficients $K_{M-A}$ for styrene-PSf and cyclopentane-PURf systems for different temperatures derived from the close-to- equilibrium theory

\begin{tabular}{c|c|c|c|c|c|c}
\hline & \multicolumn{3}{|c|}{ Styrene-PSf } & \multicolumn{3}{c}{ Cyclopentane-PURf } \\
\hline $\mathrm{T}_{,}{ }^{\circ} \mathrm{C}$ & $k_{\text {ads }}, \mathrm{s}^{-1}$ & $k_{\text {des },} \mathrm{s}^{-1}$ & $K_{M-A}$ & $k_{\text {ads }} \mathrm{s}^{-1}$ & $k_{\text {des },} \mathrm{s}^{-1}$ & $K_{M-A}$ \\
\hline 23 & $5.9 \cdot 10^{-4}$ & $1.4 \cdot 10^{-6}$ & 429 & $1.1 \cdot 10^{-3}$ & $1.3 \cdot 10^{-7}$ & 8256 \\
30 & $5.8 \cdot 10^{-4}$ & $2.1 \cdot 10^{-6}$ & 277 & $9.6 \cdot 10^{-4}$ & $2.5 \cdot 10^{-7}$ & 3901 \\
40 & $5.8 \cdot 10^{-4}$ & $3.0 \cdot 10^{-6}$ & 196 & $7.9 \cdot 10^{-4}$ & $4.0 \cdot 10^{-7}$ & 1956 \\
50 & $5.7 \cdot 10^{-4}$ & $4.3 \cdot 10^{-6}$ & 133 & $7.4 \cdot 10^{-4}$ & $6.6 \cdot 10^{-7}$ & 1126 \\
60 & $5.5 \cdot 10^{-4}$ & $7.2 \cdot 10^{-6}$ & 76 & $6.5 \cdot 10^{-4}$ & $9.6 \cdot 10^{-7}$ & 684 \\
70 & $4.7 \cdot 10^{-4}$ & $1.1 \cdot 10^{-5}$ & 41 & $5.5 \cdot 10^{-4}$ & $2.1 \cdot 10^{-6}$ & 264 \\
80 & $3.9 \cdot 10^{-4}$ & $1.6 \cdot 10^{-5}$ & 24 & $4.8 \cdot 10^{-4}$ & $3.7 \cdot 10^{-6}$ & 130 \\
90 & $1.9 \cdot 10^{-4}$ & $2.6 \cdot 10^{-5}$ & 7 & $3.8 \cdot 10^{-4}$ & $6.8 \cdot 10^{-6}$ & 56 \\
$E_{a}, \mathrm{~kJ} \cdot \mathrm{mol}^{-1}$ & $-11 \pm 4$ & $38 \pm 1$ & & $-13 \pm 1$ & $50 \pm 2$ & \\
\hline
\end{tabular}

T a b 1 e 2. Rate constants of adsorption and desorption, $k_{a d s}$ and $k_{d e s}$ and partition coefficients $K_{M-A}$ for styrene-PSf and cyclopentane-PURf systems for different temperatures derived from the computational model

\begin{tabular}{c|c|c|c|c|c|c}
\hline & \multicolumn{3}{|c|}{ Styrene-PSf } & \multicolumn{3}{c}{ Cyclopentane-PURf } \\
\hline$T,{ }^{\circ} \mathrm{C}$ & $k_{a d s}, \mathrm{~s}^{-1}$ & $k_{d e s}, \mathrm{~s}^{-1}$ & $K_{M-A}$ & $k_{a d s}, \mathrm{~s}^{-1}$ & $k_{d e s} \mathrm{~s}^{-1}$ & $K_{M-A}$ \\
\hline 23 & $2.6 \cdot 10^{-3}$ & $6.3 \cdot 10^{-6}$ & 417 & $4.1 \cdot 10^{-3}$ & $5.3 \cdot 10^{-7}$ & 7789 \\
30 & $2.7 \cdot 10^{-3}$ & $1.0 \cdot 10^{-5}$ & 268 & $3.9 \cdot 10^{-3}$ & $1.1 \cdot 10^{-6}$ & 3637 \\
40 & $2.8 \cdot 10^{-3}$ & $1.5 \cdot 10^{-5}$ & 190 & $3.7 \cdot 10^{-3}$ & $2.2 \cdot 10^{-6}$ & 1727 \\
50 & $2.9 \cdot 10^{-3}$ & $2.2 \cdot 10^{-5}$ & 131 & $3.5 \cdot 10^{-3}$ & $3.7 \cdot 10^{-6}$ & 946 \\
60 & $3.0 \cdot 10^{-3}$ & $3.9 \cdot 10^{-5}$ & 76 & $2.9 \cdot 10^{-3}$ & $5.3 \cdot 10^{-6}$ & 552 \\
70 & $2.9 \cdot 10^{-3}$ & $6.9 \cdot 10^{-5}$ & 42 & $2.1 \cdot 10^{-3}$ & $1.1 \cdot 10^{-5}$ & 184 \\
80 & $2.7 \cdot 10^{-3}$ & $1.0 \cdot 10^{-4}$ & 26 & $2.1 \cdot 10^{-3}$ & $2.4 \cdot 10^{-5}$ & 88 \\
90 & $1.8 \cdot 10^{-3}$ & $1.9 \cdot 10^{-4}$ & 10 & $1.9 \cdot 10^{-3}$ & $4.7 \cdot 10^{-5}$ & 40 \\
$E_{a,}, \mathrm{~kJ} \cdot \mathrm{mol}^{-1}$ & $-2 \pm 2$ & $43 \pm 2$ & & $-11 \pm 1$ & $57 \pm 2$ & \\
\hline
\end{tabular}

As shown in Table 1 and 2, the values of $k_{\text {ads }}$ and $k_{\text {des }}$ obtained from equation (3) are on average one order of magnitude lower than those obtained from the computer simulations at the same temperatures, the difference between them increasing with an increase in temperature. However, their regular variations with temperature between 23 and $90^{\circ} \mathrm{C}$ within each set of results revealed certain characteristic behaviors of the analysed systems. First, as expected, the adsorption exceeded the desorption in both styrene-PSf and cyclopentane-PURf systems, the rate constants of desorption being one to four orders of magnitude lower than those of adsorption at the same temperatures. This implies that the compounds favor remaining in a foam rather than in gas phase. Second, the adsorption rate constants $k_{\text {ads }}$ decreased slowly with an increase in temperature within the studied range of $23-90^{\circ} \mathrm{C}$, only two- to three-fold on average. Third, unlike the rate constants of adsorption $k_{\text {ads }}$ the rate constants of desorption $k_{\text {des }}$ increased sharply with an increase in temperature, one to two orders of magnitude within the same temperature range.

\section{Partition coefficients}

Table 1 and 2 also present the partition coefficients, $K_{M-A}$, of styrene and of cyclopentane between the respective polymer foams and gas phase, calculated from equation (2) according to the applied methods: close-to-equilibrium theory and computer simulation. In keeping with the above described trends in $k_{d e s}$ and $k_{a d s}$ variations, the $K_{M-A}$ coefficients obtained by both these methods are similar in value for each system. The partition coefficients of cyclopentane, however, are significantly higher than those of styrene, due to good sorption properties of polyurethane for VOC. The $K_{M-A}$ values obtained for styrene-PSf generally comply with the values reported in the literature, e.g. 260 at $25^{\circ} \mathrm{C}$ [29], but for cyclopentane-PURf, they are significantly different, e.g. 6 at $21^{\circ} \mathrm{C}$ [45].

From the adsorption and desorption rate constants obtained at different temperatures, the activation energies $E_{a}$ of adsorption and desorption were calculated using the Arrhenius equation:

$$
k=A e^{-\frac{E_{a}}{R T}}
$$

The results are also compiled in Table 1 and 2. For adsorption, $E_{a}$ appeared to have a negative value both for styrene and cyclopentane, thereby indicating the tendency of the compounds to remain in the foams. Generally, processes exhibiting negative activation energies are typically barrierless. Indeed, the activation energies of organic adsorption on polymers are known to be low, often close to zero [46]. This is why the heat of adsorption may be viewed as corresponding to the activation energies of desorption, shown here to have relatively high positive values. For instance, in a study of hydrocarbon desorption $\left(\mathrm{C}_{6}-\mathrm{C}_{14}\right)$ on low density polyethylene, enthalpies of desorption between $33.7 \mathrm{~kJ} \mathrm{~mol}^{-1}$ (2,4-dimethylheptane) and $87.1 \mathrm{~kJ} \mathrm{~mol}^{-1}$ (alkene $\mathrm{C}_{11}$ ) were recorded [47]. In another study, the measurements of styrene sorption on polystyrene by inversed gas chromatography (IGC) technique at temperatures between 70 and $120^{\circ} \mathrm{C}$ produced the heat of sorption equal to 42 and $71 \mathrm{~kJ}$ $\mathrm{mol}^{-1}$ below and above glass transition $\left(\sim 95^{\circ} \mathrm{C}\right)$, respectively [19]. In conclusion, it can be stated that both models applied generated consistent values of the activation energy of desorption that are in agreement with the literature data.

In addition to the partition coefficients $K_{M-A}$ of styrene and cyclopentane between the respective foams and the ambient air, also their internal partition coefficients $K_{P-C}$ 
corresponding to the polymer-cell systems, were obtained from the experimental data. The coefficients were computed using equation (6) and their values are presented in Table 3. Their values were found to be higher than those reported in the literature for bulk polymers (systems polymer-air) and composites. The typical values of such partition coefficients commonly fall in the range from several thousands at room temperature to a few hundreds at $80{ }^{\circ} \mathrm{C}[24,48]$, depending on the chemical affinity and VOC molecular weight. For instance, for styrene on solid polystyrene, the partition coefficients amount to $67-6.5$ in the temperature range from 70 to $110{ }^{\circ} \mathrm{C}$ [19]. When extrapolated to $20^{\circ} \mathrm{C}$, the above data give the partition coefficient equal to 10500 , i.e. some three times lower than the internal partition coefficient obtained in this study. Unlike for polystyrene, there are no direct literature reports on partition of homogeneous solid polyurethane. For polyurethane foam, however, the values of cyclopentane partition coefficients calculated from the solubility coefficients for the polyurethane phase extracted from the foam [36], amount to $100000-$ 280000 at $23-25{ }^{\circ} \mathrm{C}$.

$\mathrm{T}$ a b l e 3. Internal partition coefficients $K_{P-C}$ for styrene in PSf and of cyclopentane in PURf

\begin{tabular}{c|c|c}
\hline$T,{ }^{\circ} \mathrm{C}$ & Styrene-PSf & Cyclopentane-PURf \\
\hline 23 & 32243 & 214475 \\
30 & 21426 & 102023 \\
40 & 15690 & 51412 \\
50 & 11279 & 29908 \\
60 & 7274 & 18504 \\
70 & 4793 & 7622 \\
80 & 3600 & 4144 \\
90 & 2427 & 2184 \\
\hline
\end{tabular}

Owing to the complex geometrical structure of both polymers and cell phases in the foams, in our opinion internal partition coefficients $K_{P-C}$ should be treated as ex- perimental parameters rather than coefficients describing the true VOC polymer/external phase partition. This notwithstanding, the coefficients constitute an effort to acquire effective and practical parameters that could be used in further calculations of diffusion coefficients.

\section{Diffusion coefficients}

The diffusion coefficients of styrene in PSf and of cyclopentane in PURf were obtained from the three proposed models - sorption, permeation and computer simulation; accordingly they were designated as $D_{S}, D_{P}$ and $D_{C}$. The coefficients $D_{P}$ and $D_{S}$ were calculated from equation (7) and (8), respectively, wherein the data needed for calculations, i.e. the concentration of the compounds in the foams and the mass of the compounds desorbed from the foams, were read out from the emission kinetic curves (Fig. 1). Due to discrete character of concentration data, $D_{P}$ was calculated using differential form of equation (7) by summation over the time before the equilibrium was estabilished. The coefficient $D_{C}$, by contrast, was a parameter in the computational simulations used together with the adsorption and desorption rate constants to describe the observed courses of emissions. The results are presented in Table 4.

The values of $D$ differ from each other by one to four orders of magnitude, depending on the system and temperature. The computer-simulation derived values $D_{C}$ are always lower than those experimentally derived using sorption $D_{S}$ and permeation $D_{P}$ models, whereas the $D_{S}$ values are always higher (styrene-PSf) or rather lower (cyclopentane-PURf) than the $D_{P}$ values. Apparently, these disparities seen in the diffusion coefficients originate from the assumptions made in each model applied showing how big an impact the data analysis chosen has on the final values [49]. For comparison purposes, Table 5 gives a selection of diffusion coefficients reported in the literature for the same VOC-foam systems, however for the foams of higher densities. In case of the styrene-PSf system, the computer simulation generated results most comparable to diffusion coefficients quoted in

T a b l e 4. Diffusion coefficients [calculated from the permeation $\left(D_{P}\right)$, sorption $\left(D_{S}\right)$ and computer simulation $\left(D_{C}\right)$ models] of styrene in PSf and of cyclopentane in PURf

\begin{tabular}{|c|c|c|c|c|c|c|}
\hline \multirow[b]{2}{*}{$T,{ }^{\circ} \mathrm{C}$} & \multicolumn{3}{|c|}{ Styrene-PSf (density $0.025 \mathrm{~g} \mathrm{~cm}^{-3}$ ) } & \multicolumn{3}{|c|}{ Cyclopentane-PURf (density $0.037 \mathrm{~g} \mathrm{~cm}^{-3}$ ) } \\
\hline & $D_{P}, \mathrm{~cm}^{2} \mathrm{~s}^{-1}$ & $D_{S}, \mathrm{~cm}^{2} \mathrm{~s}^{-1}$ & $D_{C}, \mathrm{~cm}^{2} \mathrm{~s}^{-1}$ & $D_{P}, \mathrm{~cm}^{2} \mathrm{~s}^{-1}$ & $D_{S,} \mathrm{~cm}^{2} \mathrm{~s}^{-1}$ & $D_{C}, \mathrm{~cm}^{2} \mathrm{~s}^{-1}$ \\
\hline 23 & $1.6 \cdot 10^{-9}$ & $1.7 \cdot 10^{-8}$ & $8.6 \cdot 10^{-11}$ & $7.5 \cdot 10^{-10}$ & $8.2 \cdot 10^{-11}$ & $3.3 \cdot 10^{-14}$ \\
\hline 30 & $2.3 \cdot 10^{-9}$ & $3.8 \cdot 10^{-8}$ & $1.6 \cdot 10^{-10}$ & $1.5 \cdot 10^{-9}$ & $4.0 \cdot 10^{-10}$ & $2.0 \cdot 10^{-13}$ \\
\hline 40 & $3.2 \cdot 10^{-9}$ & $7.2 \cdot 10^{-8}$ & $2.8 \cdot 10^{-10}$ & $3.0 \cdot 10^{-9}$ & $1.5 \cdot 10^{-9}$ & $1.1 \cdot 10^{-12}$ \\
\hline 50 & $4.5 \cdot 10^{-9}$ & $1.4 \cdot 10^{-7}$ & $4.7 \cdot 10^{-10}$ & $5.2 \cdot 10^{-9}$ & $4.5 \cdot 10^{-9}$ & $5.1 \cdot 10^{-12}$ \\
\hline 60 & $6.9 \cdot 10^{-9}$ & $3.3 \cdot 10^{-7}$ & $7.8 \cdot 10^{-10}$ & $8.4 \cdot 10^{-8}$ & $1.2 \cdot 10^{-8}$ & $2.2 \cdot 10^{-11}$ \\
\hline 70 & $1.1 \cdot 10^{-8}$ & $7.7 \cdot 10^{-7}$ & $1.3 \cdot 10^{-9}$ & $2.0 \cdot 10^{-8}$ & $6.7 \cdot 10^{-8}$ & $9.6 \cdot 10^{-11}$ \\
\hline 80 & $1.4 \cdot 10^{-8}$ & $1.4 \cdot 10^{-6}$ & $1.9 \cdot 10^{-9}$ & $3.8 \cdot 10^{-8}$ & $2.2 \cdot 10^{-7}$ & $3.0 \cdot 10^{-10}$ \\
\hline 90 & $2.1 \cdot 10^{-8}$ & $3.0 \cdot 10^{-6}$ & $2.9 \cdot 10^{-9}$ & $7.1 \cdot 10^{-8}$ & $7.9 \cdot 10^{-7}$ & $1.2 \cdot 10^{-9}$ \\
\hline$E_{a}, \mathrm{~kJ} \mathrm{~mol}^{-1}$ & $33 \pm 1$ & $68 \pm 2$ & $48 \pm 2$ & $59 \pm 2$ & $117 \pm 4$ & $137 \pm 3$ \\
\hline
\end{tabular}


the literature. Permeation assumption delivered good consistence of $D$ data for cyclopentane-PURf system.

$\mathrm{T}$ a b 1 e 5. Diffusion coefficients of styrene in PSf (density $0.042-0.114 \mathrm{~g} \cdot \mathrm{cm}^{-3}$ ) [3] and of cyclopentane in PURf (density $\left.0.061-0.071 \mathrm{~g} \cdot \mathrm{cm}^{-3}\right)[50]$ reported in the literature

\begin{tabular}{c|c|c}
\hline & Styrene-PSf & Cyclopentane-PURf \\
\hline$T,{ }^{\circ} \mathrm{C}$ & $D_{S}, \mathrm{~cm}^{2} \mathrm{~s}^{-1}$ & $D_{P}, \mathrm{~cm}^{2} \mathrm{~s}^{-1}$ \\
\hline 4.5 & $8.8 \cdot 10^{-12}$ & - \\
21 & $(1.0-8.8) \cdot 10^{-11}$ & - \\
23 & - & $6 \cdot 10^{-10}$ \\
25 & $6.2 \cdot 10^{-8 *)}$ & - \\
40 & - & $4 \cdot 10^{-9}$ \\
49 & $(2.7-9.5) \cdot 10^{-10}$ & - \\
60 & - & $7 \cdot 10^{-9}$ \\
66 & $(2.5-4.8) \cdot 10^{-9}$ & - \\
90 & & $1 \cdot 10^{-8}$ \\
$E_{a}, \mathrm{~kJ} \mathrm{~mol}-1$ & $79-100$ & $60^{* *)}$ \\
\hline
\end{tabular}

*) Data taken from ref. [29].

**) $23-60{ }^{\circ} \mathrm{C}$.

In all the cases studied the diffusion coefficients increased with temperature, resulting in positive activation energies of diffusion (Table 4). Values of energies were found to be two times higher for $D_{S}$ in comparison to $D_{P}$. The magnitudes of the energies, like the diffusion coefficients, depended on the model applied. Their magnitudes are comparable with those reported in the literature (Table 5).

\section{CONCLUSIONS}

This work presents results of experiments aiming at quantification of emissions of styrene from polystyrene foam (PSf) and of cyclopentane from polyurethane foam (PURf). Two approaches were applied to determine the adsorption and desorption rate constants of the VOC, and three models, based on sorption, permeation and computer simulation, to determine the diffusion coefficients. A gas chromatograph-coupled measurement chamber was applied - which enabled the elimination of the pre-concentration procedures of the analyzed gases. The mass detector proved to give satisfactory detection limits as well as linearity over wide VOC concentration ranges and expected precision. The emission measurements were done in static conditions, at temperatures within the range of $23-90^{\circ} \mathrm{C}$.

The release of the VOC from the foams expressed by a chromatographic peak area over time was best described by a hyperbolic function. The partition coefficients of the VOC between the respective foams and air were determined as the ratio of the rate constants of adsorption to desorption. The rate constants were obtained using two methods, namely the close-to-equilibrium approach and a computer simulation, where the rate constants together with the effective diffusion coefficients were iterative parameters relating the experimental data with the simulation of the concentration distribution inside the foams. The $k_{a d s}$ and $k_{\text {des }}$ values for both styrene and cyclopentane obtained by the simulation were found higher than by the close-to-equilibrium approach, but the partition coefficients determined by both methods were comparable. Unlike the partition coefficients, the adsorption/desorption rate constants for the studied systems are not available in the literature.

On the basis of the sorption, permeation and computational models, three different sets of diffusion coefficients were obtained for each studied system within the chosen temperature range. The computer-simulation derived diffusion coefficients were found to be comparable with the literature data for the system that consisted of relative low migrant concentrations in the foam (styrene-PSf), while for the system where migrant concentrations in the foam were significantly higher (cyclopentane-PURf) - permeation model was applied. The different $D$ coefficients varying among the models generated different values of the activation energy; good agreement between the experimental results and literature data was observed for $D_{P}$ in cyclopentane-PURf system.

\section{REFERENCES}

1. Yu C., Crump D.: Build. Environ. 1998, 33, 57.

2. Haghighat F., de Bellis L.: Build. Environ. 1998, 33, 261.

3. Lickly T. D., Lehr K. M., Welsh G. C.: Food Chem. Toxicol. 1995, 33, 475.

4. Wolkoff P.: Indoor Air Suppl. 1995, 3, 9.

5. Wolkoff P.: Sci. Total Environ. 1999, 227, 197.

6. Bart G. C. J., Du Cauze De Nazelle G. M. R.: J. Cell. Plast. 1993, 29, 29.

7. Crump D., Squire R. W., Yu C. W. F.: Indoor and Built Environ. 1997, 6, 45.

8. Singh S. N., Nitru M., Dedecker K.: J. Cell. Plast. 2003, 39, 265.

9. Wolkoff P.: Atmos. Environ. 1998, 329, 2659.

10. Huang H., Haghighat F.: Build. Environ. 2002, 37, 1349.

11. Haghighat F., Huang H.: Build. Environ. 2003, 38, 1007.

12. Lickly T. D., Breder C. V., Rainey M. L.: Regul. Toxicol. Pharm. 1995, 21, 406.

13. Reid R. C., Sidman K. R., Schwope A. D., Till D. E.: Ind. Eng. Chem. Prod. Res. Dev. 1980, 19, 580.

14. Trzeszczyński J., Huzar E.: Chromatographia 2001, 53, 534.

15. Wenzl T., Lankmayr E. P.: Anal. Bioanal. Chem. 2002, 372, 649.

16. Chai X.-S., Hou Q. X., Schork F. J.: J. Chromatogr. 2004, A1040, 163.

17. Cox S. S., Zhao D., Little J. C.: Atmos. Environ. 2001, 35, 3823.

18. Zhao D., Little J. C., Cox S. S.: J. Environ. Eng. 2004, 130, 983.

19. Miltz J., Rosen-Doddy V.: Eur. Polym. J. 1986, 22, 327.

20. Kontominas M. G., Gavara R., Giacin J. R.: Eur. Polym. J. 1994, 30, 265. 
21. Grate J. W., Klusty M., McGill R. A., Abraham M. H., Whiting G., Andonian-Haftvan J.: Anal. Chem. 1992, 64, 610.

22. Martos P. A., Pawliszyn J.: Anal. Chem. 1997, 69, 206.

23. De Coensel N., Desmet K., Górecki T., Sandra P.: J. Chromatogr. 2007, A1150, 183.

24. Grate J. W., Kaganove S. N., Bhethanabotla V. R.: Anal. Chem. 1998, 70, 199.

25. Bawn C. E. H., Patel R. D.: Trans. Faraday Soc. 1956, 52, 1664.

26. Jřr rgensen R. B., Bjřr rseth O., Malvik B.: Indoor Air 1999, 9, 2.

27. Jřr rgensen R. B., Dokka T. H., Bjřr rseth O.: Indoor Air 2000, 10, 27.

28. Crank J.: In "Diffusion in Polymers" (Eds. Crank J., Park G. S.), Academic Press Inc., London, New York 1968, pp. 1-39.

29. Yuan H., Little J. C., Hodgson A. T.: Atmos. Environ. 2007, 41, 3241.

30. Perez-Blanco M., Hammons R. J., Danner R. P.: J. Appl. Polym. Sci. 2010, 116, 2359.

31. Vopička O., Hynek V., Friess K., Šipek M., Sysel P.: Chem. Listy 2009, 103, 310.

32. Choi O. K., Jitsunari F., Asakawa F., Lee D. S.: Food Addit. Contam. 2005, 22, 693.

33. Fialová K., Petrychkovych R., Sharma M., Uchytil P.: J. Membr. Sci. 2006, 275, 166.

34. Uchytil P., Petričkovič R.: J. Membr. Sci. 2002, 209, 67.

35. Maddinelli G., Iwanski P., Callaioli A., Ravanetti G. P.: Int. J. Polym. Anal. Ch. 2006, 11, 147.
36. Mangs S.: "Insulation Materials in District Heating Pipes", PhD thesis, Chalmers University of Technology, Göteborg, Sweden 2005.

37. Yang X., Chen Q., Zhang J. S., Magee R., Zeng J., Shaw C. Y.: Build. Environ. 2001, 36, 1099.

38. Meininghaus R., Gunnarsen L., Knudsen H. N.: Environ. Sci. Technol. 2000, 34, 3101.

39. Murakami S., Kato S., Ito K., Zhu Q.: Indoor Air 2003, 13 Suppl 6, 20.

40. Klopffer M. H., Flaconneche B.: Oil Gas Sci. Technol. 2001, 56, 223.

41. Soney C. G., Sabu T.: Prog. Polym. Sci. 2001, 26, 985.

42. Atkins P. W.: "Physical Chemistry", PWN, Warszawa 2001, pp. $735-763$.

43. Lagarias J. C., Reeds J. A., Wright M. H., Wright P. E.: SIAM J. Optimiz. 1998, 9, 112.

44. Ritter J. J., Adams N. K.: Anal. Chem. 1976, 48, 612.

45. Kamprad I., Goss K.-U.: Anal. Chem. 2007, 79, 4222.

46. ten Hulscher Th. E. M., Cornelissen G.: Chemosphere 1996, 32, 609.

47. Hodgson S. C., O'Connor M. J., Casey R. J., Bigger S. W.: J. Agric. Food Chem. 1998, 46, 1397.

48. Sabzi F., Boushehri A.: Eur. Polym. J. 2005, 41, 2067.

49. Haghighat F., Lee C.-S., Ghaly W. S.: Indoor Air 2002, 12, 81.

50. Olson M. E., Ulf J., Fröling M., Mangs S., Ramnäs O.: J. Cell. Plast. 2002, 38, 177.

Received 24 VI 2010. 